\author{
ELŻBIETA MAŁECKA \\ ORCID: 0000-0002-1484-1383 \\ Uniwersytet Rzeszowski \\ elzbieta_malecka@interia.eu
}

\title{
Prawnoadministracyjne instrumenty ochrony przedsiębiorców narażonych na stosowanie praktyk monopolistycznych przysługujące Prezesowi Urzędu Transportu Kolejowego - uwagi na gruncie obowiązujących i projektowanych przepisów prawa
}

\begin{abstract}
Abstrakt: Celem opracowania jest analiza obowiązujących i projektowanych przepisów dotyczących prawno-administracyjnych instrumentów ochrony przedsiębiorców narażonych na stosowanie praktyk monopolistycznych przysługujących Prezesowi Urzędu Transportu Kolejowego. Przepisy ustawy z dnia 28 marca 2003 roku o transporcie kolejowym (tekst jedn. Dz.U. z 2019 r. poz. 710) nakładają na Prezesa UTK takie zadania, jak nadzór nad sprawiedliwym i niedyskryminującym traktowaniem przez zarządców wszystkich aplikantów w zakresie dostępu do infrastruktury kolejowej oraz nadzór nad sprawiedliwym i niedyskryminującym traktowaniem przez operatorów obiektu infrastruktury usługowej wszystkich przewoźników kolejowych w zakresie dostępu do obiektu infrastruktury usługowej. Aktualnie procedowane są dwa projekty nowelizacji prawa transportu kolejowego rozszerzające katalog zadań i kompetencji Prezesa UTK.
\end{abstract}

Stowa kluczowe: Prezes UTK, praktyki monopolistyczne, transport kolejowy.

\section{Uwagi wstępne}

Cel artykułu stanowi analiza obowiązujących i projektowanych przepisów dotyczących prawno-administracyjnych instrumentów ochrony przedsiębiorców narażonych na stosowanie praktyk monopolistycznych przysługujących Prezesowi Urzędu Transportu Kolejowego. Teza artykułu sprowadza się do twierdzenia, 
że w kolejnych nowelizacjach prawa transportu kolejowego nie jest dostrzegany problem braku przepisów szczegółowych, dzięki którym Prezes UTK może w pełni realizować swoje zadania i kompetencje.

Przepisy ustawy z dnia 28 marca 2003 roku o transporcie kolejowym ${ }^{1}$ nakładają na Prezesa UTK zadania nadzorcze wiążące się z ochroną przedsiębiorców narażonych na stosowanie praktyk monopolistycznych. Aktualnie procedowane są dwa projekty nowelizacji prawa transportu kolejowego rozszerzające katalog zadań Prezesa UTK - projekt ustawy o zmianie ustawy o transporcie kolejowym oraz niektórych innych ustaw (UD 530), zwany projektem z 20 maja 2019 roku $^{2}$, oraz projekt ustawy o zmianie ustawy o transporcie kolejowym oraz ustawy o komercjalizacji i restrukturyzacji przedsiębiorstwa państwowego „Polskie Koleje Państwowe" (UC 139), zwany projektem z 23 maja 2019 roku $^{3}$.

Główną płaszczyzną prowadzonych rozważań będą przepisy prawa. Analizie zostaną poddane również opracowania naukowe, a także dane i uwagi przekazane autorce dzięki uprzejmości Marcina Treli, dyrektora Departamentu Obsługi Prawnej UTK. W opracowaniu zostały zastosowane metody: dogmatyczno-prawna oraz analityczno-syntetyczna. W pierwszej kolejności z dostępnych materiałów zostały wybrane elementy związane $\mathrm{z}$ omawianym tematem, $\mathrm{w}$ drugiej, została dokonana analiza semantyczna, komparatystyczna oraz strukturalna.

\section{Instrumenty prawne działania Prezesa UTK}

Zadania i kompetencje Prezesa UTK mają charakter regulacyjny, jednakże możliwość zakwalifikowania Prezesa UTK jako organu stricte regulacyjnego budzi wątpliwości w doktrynie prawa administracyjnego. Jednym ze źródeł tych trudności kwalifikacyjnych jest fakt, iż sfera zadań i kompetencji Prezesa UTK ewoluowała wraz z akcesją Polski do Unii Europejskiej. Przebiegała ona w kierunku uczynienia z niego krajowego regulatora sektora kolejowego, który wykonuje swe zadania i kompetencje w ramach europejskiej sieci administracji. Zmiany te są skorelowane z zadaniami i kompetencjami przynależnymi do pierwotnej, reglamentacyjnej oraz policyjnej funkcji tego organu ${ }^{4}$.

Kolejne pakiety kolejowe przyjmowane przez Komisję Europejską wpływały na rozszerzanie zakresu obowiązków i kompetencji regulatorów kolejo-

1 Tekst jedn. Dz.U. z 2019 r. poz. 710, dalej: TKU.

2 https://legislacja.rcl.gov.pl/projekt/12321775/katalog/12592297\#12592297 (dostęp: 20.09.2019).

3 https://legislacja.rcl.gov.pl/projekt/12321831/katalog/12594839\#12594839 (dostęp: 20.09.2019).

${ }^{4}$ M. Goss, Charakter prawny zadań i kompetencji Prezesa UTK w obszarze interoperacyjności europejskiej sieci kolejowej ze szczególnym uwzględnieniem zezwoleń na dopuszczenie do eksploatacji pojazdu kolejowego zgodnego z TSI, „Internetowy Kwartalnik Antymonopolowy i Regulacyjny" 2017, $\mathrm{nr} 4$ (6), s. 62. 
wych w krajach członkowskich, przesuwając punkt ciężkości z kwestii technicznych w kierunku regulacji ekonomicznej rynku kolejowego i ochrony konkurencji. Przy czym, ze względu na odmienność ram instytucjonalnych sektora kolejowego, w poszczególnych krajach rola wyspecjalizowanych regulatorów kolejowych jest różna, a wdrożenie ujednoliconego modelu w praktyce jest zadaniem niezwykle trudnym. Należy jednocześnie zauważyć, że w świetle unormowań zawartych w IV pakiecie kolejowym znaczenie regulatora unijnego ma wzrastać. Zadanie ERA to, z jednej strony, ustalanie zunifikowanych norm w dziedzinie bezpieczeństwa transportu kolejowego oraz interoperacyjności, a z drugiej - kontrola ich przestrzegania przez poszczególne państwa ${ }^{5}$. Wymaga to bliskiej współpracy Europejskiej Agencji Kolejowej z narodowymi regulatorami rynków kolejowych ${ }^{6}$.

Jan Pieriegud, oceniając działalność UTK dziesięć lat po powstaniu, wskazywał na stosunkowo szerokie kompetencje w zakresie regulacji transportu kolejowego w Polsce. Podkreślił również, że w ostatnich latach podjęto wiele działań, między innymi w zakresie kształtowania stawek dostępu czy przestrzegania praw pasażerów, które przyczyniły się do wzmocnienia roli Prezesa UTK jako regulatora krajowego rynku kolejowego ${ }^{7}$. Zdaniem przywołanego autora umiejscowienie tego organu w strukturze administracji rządowej i przyporządkowanie jego działań ministrowi właściwemu do spraw transportu, który nadzoruje również działalność państwowego zarządcy infrastruktury, tworzy źródło konfliktu interesów i nie sprzyja rozwojowi konkurencji na polskim rynku kolejowym ${ }^{8}$.

Analiza zadań i kompetencji Prezesa UTK prowadzi do pytania o instrumenty regulacyjne przysługujące temu organowi. Piotr Lissoń, rozpatrując formy oraz instrumenty prawne działania organu regulacyjnego na przykładzie Prezesa Urzędu Regulacji Energetyki, podejmuje próbę uporządkowania instrumentów działania administracji w kontekście regulacji, dokonując przeglądu podziałów prezentowanych w doktrynie. Są to między innymi:

1. za Tadeuszem Skocznym - instrumenty „służące regulacji uczestnictwa w rynku” oraz instrumenty „służące regulacji zachowań przedsiębiorstw”, wyróżnione ze względu na kryterium przedmiotu regulacji;

2. za Kazimierzem Strzyczkowskim — środki prawne reglamentacji, nadzoru, kontroli, rozstrzygania sporu oraz nakładania kar, wyróżnione ze względu na kryterium funkcji organu;

3. za Anną Walaszek-Pyzioł - instrumenty władcze i niewładcze, wyróżnione ze względu na kryterium formalne;

5 Szerzej J. Engelhardt, Czwarty pakiet kolejowy - zarządzanie infrastruktura kolejowa, „Problemy Transportu i Logistyki” 2018, nr 1 (41), s. 53 n.

6 J. Pieriegud, Rola i funkcje regulatorów w transporcie kolejowym, ,Internetowy Kwartalnik Antymonopolowy i Regulacyjny" 2015, nr 1 (4), s. 89.

7 Zob. K. Dyl, Działania regulacyjne Prezesa Urzędu Transportu Kolejowego w latach 20112014, „Internetowy Kwartalnik Antymonopolowy i Regulacyjny” 2015, nr 1 (4), s. 10 n.

8 J. Pieriegud, op. cit., s. 89. 
4. za Waldemarem Hoffem - decyzje regulacyjne sensu stricto, decyzje o przewadze elementów administracyjno-prawnych oraz działania pomocnicze regulacji, wyróżnione ze względu na kryterium formy prawnej podejmowanych działan 9 .

W świetle art. 13 TKU najwięcej zadań Prezesa UTK ma charakter nadzorczy. Dlatego warta zauważenia jest koncepcja nadzoru regulacyjnego przywołana w artykule Mikołaja Gossa. Autor ten wskazuje, że nadzór regulacyjny wykonywany jest przez regulatora na dwóch płaszczyznach — w relacji organ i konkretny przedsiębiorca oraz $\mathrm{w}$ relacji organ i dany sektor.

Pierwsza płaszczyzna obejmuje wieloaspektową weryfikację działalności danego podmiotu pod kątem jej zgodności z przyjętą przez regulatora docelową wizją rynku i jego uczestników. Wśród problemów, które znajdują się w obszarze zainteresowania regulatora, znajduje się nie tylko spełnianie przez dany podmiot wymogów formalnych uczestnictwa w danym sektorze (na przykład posiadanie zezwolenia lub licencji określonego typu, przyjęcie określonych procedur w zakresie bezpieczeństwa czy obsługi pasażera), ale także kwestia dysponowania określonym potencjałem technicznym oraz kadrowym, powiązanym z przyjętym celem regulacyjnym. Osiągnięciu tych celów służą w większości przypadków instrumenty wykorzystywane także $\mathrm{w}$ tradycyjnie pojmowanej reglamentacji, w tym indywidualne akty administracyjne niezbędne do prowadzenia działalności danego typu. Rola ich jednakże jest odmienna, gdyż zauważalne jest ich powiązanie z zagadnieniem konkurencji.

Druga z płaszczyzn, na których wykonywany jest nadzór regulacyjny, nakierowana jest na relację organ i ogół uczestników danego rynku. W jej ramach regulator prowadzi systematyczne działania zmierzające do urzeczywistnienia w ramach danego sektora odpowiedniego stanu konkurencji. Działanie to ma charakter etapowy. Organ regulacyjny monitoruje sytuację bieżącą, w szczególności pod kątem występowania niedozwolonych działań ze strony uczestników rynku, których skutkiem lub celem byłoby stworzenie niepożądanych przez regulatora barier ograniczających w sposób nieuprawniony dostęp nowym podmiotom ${ }^{10}$.

\section{Instrumenty prawno-administracyjne przysługujące Prezesowi UTK na podstawie przepisów TKU}

Do zadań w zakresie regulacji transportu kolejowego mających na celu między innymi ochronę przedsiębiorców narażonych na stosowanie praktyk monopo-

9 P. Lissoń, Formy oraz instrumenty prawne działania organu regulacyjnego na przykładzie Prezesa Urzędu Regulacji Energetyki, [w:] Instrumenty i formy prawne działania administracji gospodarczej, red. B. Popowska, K. Kokocińska, Poznań 2009, s. 326.

10 M. Goss, op. cit., s. 67 n. 
listycznych, realizowanych na podstawie art. 13 TKU przez Prezesa UTK, należy nadzór nad sprawiedliwym i niedyskryminującym traktowaniem przez zarządców wszystkich aplikantów w zakresie dostępu do infrastruktury kolejowej. Obejmuje on: kontrolę poprawności opracowania oraz stosowania regulaminu sieci, nadzór nad zawieraniem umów o przydzielenie zdolności przepustowej oraz o wykorzystanie zdolności przepustowej, rozpatrywanie spraw dotyczących pasażerskich przewozów okazjonalnych oraz nadzór nad poprawnością ustalania i pobierania przez zarządcę opłat za udostępnianie infrastruktury kolejowej. Następnym zadaniem jest nadzór nad sprawiedliwym i niedyskryminującym traktowaniem przez operatorów obiektu infrastruktury usługowej wszystkich przewoźników kolejowych w zakresie dostępu do obiektu infrastruktury usługowej wykonywany poprzez kontrolę poprawności opracowania oraz stosowania regulaminu dostępu do obiektu infrastruktury usługowej, nadzór nad zawieraniem umów z operatorami obiektu infrastruktury usługowej oraz nadzór nad poprawnością ustalania i pobierania przez operatora obiektu infrastruktury usługowej opłat za korzystanie z obiektu infrastruktury usługowej. Kolejne zadania to opiniowanie projektów umów o świadczenie usług publicznych, wydawanie decyzji w sprawie przydzielenia zdolności przepustowej, wydawanie decyzji o przyznaniu otwartego dostępu.

Analizując przepisy TKU, w pierwszej kolejności należy zauważyć, że brakuje przepisów szczegółowych, które określałyby, w jaki sposób Prezes UTK ma realizować część z tych zadań ${ }^{11}$. Dobrym przykładem jest problematyka decyzji o przyznaniu otwartego dostępu, do której odnoszą się przepisy art. 29 TKU. Analogiczne rozwiązanie polegające na zastąpieniu umowy o udostępnienie infrastruktury kolejowej decyzją Prezesa UTK zawiera Prawo telekomunikacyjne przewidujące procedurę zastąpienia umowy o dostępie telekomunikacyjnym decyzją Prezesa Urzędu Komunikacji Elektronicznej o dostępie telekomunikacyjnym. Zwraca uwagę dopuszczalny zakres ingerencji Prezesa UKE w relacje między podmiotami, który jest szerszy, co wprost wynika z przepisów Prawa telekomunikacyjnego. Na podstawie przepisów art. 28 tej ustawy Prezes UKE, jeśli zaistnieją określone przesłanki, wydaje decyzję o dostępie telekomunikacyjnym $\mathrm{w}$ przepisanym terminie. Wskazany przepis zawiera również kryteria, którymi musi kierować się organ przy wydawaniu tej decyzji — przy czym kwestią decydującą jest zawsze wola stron, a w związku z tym Prezes UKE powinien kierować się ustaleniami i stanowiskami stron, o ile nie naruszają one przepisów prawa. W odróżnieniu od TKU Prawo telekomunikacyjne szczegółowo wskazuje kryteria, którymi podczas wydawania decyzji powinien kierować się Prezes UKE ${ }^{12}$.

11 Badania własne autorki, wywiad e-mailowy z Marcinem Trelą, dyrektorem Departamentu Obsługi Prawnej UTK, 9 września 2019.

12 F. Dopierała, Kompetencje Prezesa UTK a swoboda kształtowania umów pomiędzy zarządca infrastruktury a przewoźnikiem, „Internetowy Kwartalnik Antymonopolowy i Regulacyjny” 2013, nr 4 (2), s. 58. 
Kolejnym problemem jest niestworzenie odpowiedniego katalogu kar pieniężnych, co wskazuje na konieczną w tym zakresie stosowną nowelizację art. 66 TKU na dwóch płaszczyznach. Po pierwsze, zmiana powinna dotyczyć samego katalogu kar, tak aby były one zbieżne z zadaniami nałożonymi na Prezesa UTK oraz wzmacniały instrumenty przysługujące temu organowi. Nie powinno dochodzić do sytuacji, w której organ może jedynie wskazać operatorowi, zarządcy lub przewoźnikowi kolejowemu nieprawidłowości. Po drugie, istnieje potrzeba wprowadzenia przepisu, analogicznie jak w przepisach innych ustaw „regulacyjnych”, umożliwiającego nałożenie kary pieniężnej na podstawie szacowanego przychodu lub tak zwanego ryczałtu ${ }^{13}$. Zgodnie z art. 66 ust. 2 TKU za naruszanie przez przedsiębiorcę każdego z przepisów ust. 1 Prezes UTK nakłada, w drodze decyzji, karę pieniężną w wysokości do $2 \%$ rocznego przychodu przedsiębiorcy osiągniętego w poprzednim roku kalendarzowym. Przykładami mogą być sytuacje, w których urząd nie jest w stanie ustalić przychodu lub podawany przychód wynosi 0 złotych. Przepisy art. 210 ust. 4 Prawa telekomunikacyjnego stanowią, że jeżeli podmiot nie osiągnął w poprzednim roku kalendarzowym przychodu, za podstawę wymiaru kary przyjmuje się kwotę 10 tysięcy złotych. Ponadto, na podstawie art. 210 ust. 3 Prawa telekomunikacyjnego, Prezes UKE może ustalić podstawę wymiaru kary pieniężnej w sposób szacunkowy, jeśli dany podmiot nie dostarczył danych niezbędnych do określenia podstawy wymiaru kary pieniężnej lub gdy dostarczone dane uniemożliwiają ustalenie podstawy wymiaru kary. $\mathrm{W}$ przepisach art. 56 ust. $2 \mathrm{~g}$ i $2 \mathrm{~h}$ Prawa energetycznego zostało zastosowane inne rozwiązanie - wysokość kary pieniężnej jest określona przedziałem kwotowym.

\section{Instrumenty prawno-administracyjne przysługujące Prezesowi UTK w świetle projektowanych przepisów}

Aktualnie, jak zostało wskazane we wstępie, procedowane są dwa projektu zmian do ustawy o transporcie kolejowym określone nazwami „projekt z dnia 23 maja 2019 roku” oraz ,projekt z dnia 20 maja 2019 roku”.

\subsection{Zmiany objęte projektem z dnia 23 maja 2019 roku}

Projekt z dnia 23 maja 2019 roku ma na celu dostosowanie krajowych norm prawnych w zakresie transportu kolejowego do dyrektywy Parlamentu Europejskiego i Rady (UE) 2016/2370 z dnia 14 grudnia 2016 roku zmieniającej dyrek-

\footnotetext{
13 Badania własne autorki.
} 
tywę 2012/34/UE w odniesieniu do otwarcia rynku krajowych kolejowych przewozów pasażerskich oraz zarządzania infrastrukturą kolejową ${ }^{14}$, której termin wdrożenia upłynął w dniu 25 grudnia 2018 roku. Projekt obejmuje rozbudowanie katalogu zadań i kompetencji zawartego w art. 13 TKU o sprawowanie nadzoru nad negocjacjami, których przedmiotem są opłaty za dostęp do infrastruktury oraz zawieranie i wykonywanie umów o współpracy, oraz o rozpatrywanie skarg dotyczących prowadzenia ruchu pociągów, planowanych i nieplanowanych prac odnowieniowych i utrzymaniowych oraz naruszenia przepisów dotyczących zapewnienia niezależności zarządcy. W uzasadnieniu projektodawca nie odnosi się szerzej do tych zadań, stwierdzając jedynie, że „zmiany wprowadzane w art. 13 mają na celu rozszerzenie katalogu kompetencji Prezesa UTK, uwzględniając zmiany wprowadzane niniejszą ustawą w przepisach materialnoprawnych"15.

Podkreślenia wymaga, że Prezes UTK, odnosząc się do projektowanych zmian wprowadzanych $\mathrm{w}$ art. 13 ustawy, zaproponował uzupełnienie art. 13 ust. 1 pkt 1 lit. b ustawy o kompetencje Prezesa UTK w zakresie przydzielania i wykorzystania zdolności przepustowej oraz realizacji planów jej powiększenia. Prezes UTK argumentował, że proponowana zmiana przepisów art. 13 ustawy daje mu kompetencje w zakresie alokacji zdolności przepustowej jedynie w trybie skargowym, natomiast prawidłowe wykonywanie zadań regulatora wymaga zapewnienia organowi możliwości podejmowania działań również z urzędu ${ }^{16}$.

Proponowane nowe zadanie polegające na sprawowaniu nadzoru nad przebiegiem negocjacji między aplikantami a zarządcami dotyczących poziomu opłat za dostęp do infrastruktury kolejowej ma na celu zapewnienie niedyskryminacyjnego traktowania aplikantów, w przypadku gdy takie negocjacje są prowadzone. Ze względu na to, że negocjacje mają dotyczyć poziomu opłat, a nie stawek (zgodnie z przepisami dyrektywy), co w ocenie UTK może być mylone po wprowadzeniu ustawy, w toku roboczych konsultacji UTK zgłosił propozycję umieszczenia postanowień dotyczących negocjacji nie w art. 33, ale w oddzielnej jednostce redakcyjnej art. 34a.

Proponowany art. 34a brzmi:

Zarządca i aplikant mogą pod nadzorem Prezesa UTK prowadzić negocjacje w zakresie opłat za dostęp do infrastruktury kolejowej. Zarządca informuje Prezesa UTK o rozpoczęciu negocjacji [...]. Prezes UTK może żądać od zarządcy oraz aplikanta, w szczególności, udzielenia wszelkich wyjaśnień, przedstawienia dokumentów dotyczących negocjacji, o których mowa w ust. 1, a także może brać udział w spotkaniach negocjacyjnych zarządcy i aplikanta. Prezes UTK jest uprawnio-

14 Dz.Urz. UE L 352 z 23.12.2016, s. 1.

15 Uzasadnienie do projektu z dnia 23 maja 2019 roku, s. 18, https://legislacja.rcl.gov.pl/docs //2/12321831/12594839/12594840/dokument396826.pdf (dostęp: 30.09.2019).

16 Pismo Prezesa UTK do Ministra Infrastruktury z dnia 3 czerwca 2019 roku, DOP-WSOL.022.35.2019.2.IM dotyczące projektu ustawy o zmianie ustawy o transporcie kolejowym oraz ustawy o komercjalizacji i restrukturyzacji przedsiębiorstwa państwowego „Polskie Koleje Państwowe" (projekt z dnia 23 maja 2019 roku, numer w wykazie prac legislacyjnych Rady Ministrów: UC139), pkt 8, s. 7. 
ny do wyrażenia opinii na temat prowadzonych negocjacji. Opinia doręczana jest zarządcy oraz aplikantowi. Po zakończonych negocjacjach zarządca infrastruktury informuje Prezesa UTK o jej efektach.

Należy zwrócić uwagę, że negocjacje w tym przedmiocie nie będą obowiązkowe. Prezes UTK może wyrażać opinie, brać udział w spotkaniach, żądać dodatkowych dokumentów; ponadto Prezes UTK ma być informowany o efektach negocjacji. Przy czym stanowisko Prezesa UTK nie jest wiążące, ma mieć charakter bardziej doradczy, opiniujący. W rezultacie Prezes UTK ma się jedynie przyglądać negocjacjom (gdy będą prowadzone), nie może natomiast podejmować rozstrzygnięć, gdyż nie ma kompetencji w tym zakresie. Oczywiście w razie uznania, iż zarządca podejmuje działania naruszające zakaz niedyskryminującego traktowania aplikantów, Prezes UTK jest uprawniony do wszczęcia postępowania w sprawie naruszenia przepisów z zakresu kolejnictwa ${ }^{17}$.

Projektowane uprawnienie Prezesa UTK do rozpatrywania skarg dotyczących prowadzenia ruchu pociągów, planowanych i nieplanowanych prac odnowieniowych i utrzymaniowych oraz naruszenia przepisów dotyczących zapewnienia niezależności zarządcy oznacza poszerzenie katalogu skarg, jakie mogą wnosić przewoźnicy kolejowi. Wynika ono z konieczności pełnego wdrożenia dyrektywy 2012/34, ale jest też efektem pism, jakie napływały dla UTK. Jak wskazuje Marcin Trela, w ostatnim czasie do urzędu wpływa sporo skarg czy próśb o interwencje od przewoźników, którzy, z uwagi na prowadzone modernizacje, mają bardzo utrudnione zadanie $\mathrm{z}$ odpowiednim ułożeniem rozkładu jazdy, „zmieszczeniem swoich pociągów" w rozkładzie, poprawnym ich wytrasowaniem, rekompensatami za opóźnienie pociągu, komunikacją zastępczą ${ }^{18}$.

\subsection{Zmiany objęte projektem $\mathrm{z}$ dnia 20 maja 2019 roku}

Projekt z dnia 20 maja 2019 roku rozszerza katalog kompetencji Prezesa UTK o pełnienie funkcji niezależnego organu wyznaczonego, o którym mowa w art. 5 ust. 7 zdanie drugie rozporządzenia (WE) nr 1370/2007 Parlamentu Europejskiego i Rady z dnia 23 października 2007 roku dotyczącego usług publicznych w zakresie kolejowego i drogowego transportu pasażerskiego oraz uchylającego rozporządzenia Rady (EWG) nr 1191/69 i (EWG) nr 1107/70 ${ }^{19}$.

Jak wskazano w uzasadnieniu do Projektu, dodanie w art. 13 w ust. 1 ustawy o transporcie kolejowym punktu 6a realizuje obowiązek wyznaczenia niezależnego organu, którego zadaniem będzie ocena decyzji podjętej przez organizatora publicznego transportu zbiorowego w sytuacji wyboru operatora na podstawie art. 5 ust. 4a i 4b rozporządzenia (WE) 1370/2007. Zgodnie z przepisami roz-

\footnotetext{
17 Badania własne autorki.

18 Ibidem.

19 Dz.Urz. UE L 315 z 03.12.2007, s. 1, z późn. zm.
} 
porządzenia Parlamentu Europejskiego i Rady (UE) 2016/2338 z dnia 14 grudnia 2016 roku zmieniającego rozporządzenie (WE) nr 1370/2007 w odniesieniu do otwarcia rynku krajowych usług kolejowego transportu pasażerskiego, bezpośrednie udzielanie zamówień możliwe będzie tylko w przypadkach, o których mowa w art. 5 ust. 2, 3a i 4-5 rozporządzenia (WE) nr 1370/2007. Podlegają one ocenie przez niezależny organ:

a) gdy występuje odpowiednia, strukturalna i geograficzna, charakterystyka danego rynku i sieci obejmująca wielkość, charakterystykę popytu, złożoność sieci, odseparowanie pod względem technicznym i geograficznym oraz ze względu na charakter usługi objętej umową lub gdy skutkiem będzie poprawa jakości usług lub efektywności kosztowej, w porównaniu z poprzednio udzielonym zamówieniem (umowa o świadczenie usług w zakresie publicznego transportu zbiorowego zawierana $\mathrm{w}$ tym przypadku może być zawarta na okres 10 lat, z zastrzeżeniem art. 4 ust. 4 rozporządzenia (WE) 1370/2007);

b) gdy dotyczyć będzie świadczenia wyłącznie kolejowych usług pasażerskich przez podmiot zarządzający jednocześnie całością lub dużą częścią infrastruktury kolejowej, na której usługi są świadczone (umowa o świadczenie usług w zakresie publicznego transportu zbiorowego zawierana w tym przypadku może być zawarta na okres 10 lat, z zastrzeżeniem art. 4 ust. 4 rozporządzenia (WE) 1370/2007).

$\mathrm{Z}$ tego powodu $\mathrm{w}$ projektowanym art. $13 \mathrm{w}$ ust. $1 \mathrm{w}$ pkt $6 \mathrm{a}$ TKU pojawiło się dodatkowe zadanie, jakim jest ocena zawartych bezpośrednio umów w zakresie kolejowego transportu pasażerskiego na podstawie art. 5 ust. 4a i $4 \mathrm{~b}$ rozporządzenia (WE) 1370/2007 na wniosek podmiotu, który wykaże zainteresowanie świadczeniem usług $\mathrm{w}$ zakresie publicznego transportu zbiorowego, a który doznał szkody w wyniku decyzji podjętej przez organizatora w zakresie bezpośredniego udzielenia zamówień prowadzących do zawarcia umów o świadczenie usług publicznych w zakresie kolejowego transportu pasażerskiego ${ }^{20}$.

\section{Uwagi końcowe}

Przeprowadzone rozważania i analizy potwierdzają sformułowaną we wstępie tezę, że w kolejnych nowelizacjach prawa transportu kolejowego nie jest dostrzegany problem braku przepisów szczegółowych, dzięki którym Prezes UTK może w pełni realizować swoje zadania i kompetencje. Kolejne projekty nowelizacji TKU nie likwidują istniejących problemów dotyczących braku narzędzi umożliwiających pełną realizację zadań nałożonych na Prezesa UTK, na przykład związanych z koniecznością zmiany katalogu kar oraz sposobu ich naliczania.

${ }^{20}$ Uzasadnienie do projektu z dnia 20 maja 2019 roku, s. 17, https://legislacja.rcl.gov.pl/docs //2/12321775/12592297/12592298/dokument395565.pdf (dostęp: 30.09.2019). 
Jednocześnie należy zauważyć, że powielany jest problem znany z obowiązujących przepisów, jest rozszerzany katalog zadań i uprawnień tego organu przy jednoczesnym braku przepisów szczegółowych umożliwiających ich realizację.

\title{
Bibliografia
}

Dopierała F., Kompetencje Prezesa UTK a swoboda ksztaltowania umów pomiędzy zarządca infrastruktury a przewoźnikiem, „Internetowy Kwartalnik Antymonopolowy i Regulacyjny” 2013, $\mathrm{nr} 4(2)$.

Dyl K., Działania regulacyjne Prezesa Urzędu Transportu Kolejowego w latach 2011-2014, „Internetowy Kwartalnik Antymonopolowy i Regulacyjny” 2015, nr 1 (4).

Engelhardt J., Czwarty pakiet kolejowy - zarzadzanie infrastruktura kolejowa, „Problemy Transportu i Logistyki” 2018, nr 1 (41).

Goss M., Charakter prawny zadań i kompetencji Prezesa UTK w obszarze interoperacyjności europejskiej sieci kolejowej ze szczególnym uwzględnieniem zezwoleń na dopuszczenie do eksploatacji pojazdu kolejowego zgodnego z TSI, „Internetowy Kwartalnik Antymonopolowy i Regulacyjny" 2017, nr 4 (6).

Lissoń P., Formy oraz instrumenty prawne działania organu regulacyjnego na przyktadzie Prezesa Urzędu Regulacji Energetyki, [w:] Instrumenty i formy prawne działania administracji gospodarczej, red. B. Popowska, K. Kokocińska, Poznań 2009.

Pieriegud J., Rola i funkcje regulatorów w transporcie kolejowym, „Internetowy Kwartalnik Antymonopolowy i Regulacyjny” 2015, nr 1 (4).

\section{Legal-administrative instruments of protecting entrepreneurs exposed to monopolistic practices available to the President of the Office of Rail Transport — comments regarding the applicable and designed regulations}

\author{
Summary
}

The goal of the paper is to analyse the applicable and designed regulations regarding legal-administrative instruments of protecting entrepreneurs exposed to monopolistic practices available to the President of the Office of Rail Transport. The regulations of the Act of 28th March 2003 on rail transport (consolidated text, Journal of Laws 2019, item 710) set the following tasks for the President of the Office of Rail Transport: supervision over fair and non-discriminating treatment of all applicants by managers in relation to the access to rail infrastructure and supervision over fair and non-discriminating treatment of all railway carriers in relation to the access to service infrastructure objects by operators of a service infrastructure object. Currently, two projects of amendments of the rail transport law extending the catalogue of tasks of the President of the Office of Rail Transport are underway.

Keywords: President of the Office of Rail Transport, monopolistic practices, rail transport. 